\title{
BLINDSTITCH MACHINES FOR MEN SUIT MANUFACTURING PART 1
}

\section{Ineta Nemeša}

Technical faculty “Mihajlo Pupin”, University of Novi Sad, Zrenjanin, Serbia *e-mail: inetavil@gmail.com
Professional paper

UDC: 687.1:646.4

doi: $10.5937 /$ tekstind2102034N

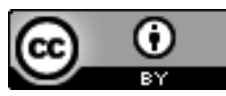

Abstract: Garment industry has developed different kind of machinery which replaces traditional manual blindstitchig techniques to ensure much higher work productivity. Many companies produce universal and specialized blindstitch machines for men suit manufacturing. To create invisible stitches of class 100 and 300, blind stitch machine uses a curved needle. The machines perform 1:1, 1:2 and 1:3.stitch pattern. The advanced machines secure the end of the seam creating invisible thread knot or forming several spot/tack stitches. The machines use to have automatic thread cutter, presser foot lifter and needle positioner. The machines for different quality materials are available. For specific applications machines are equipped with different auxiliary devices. Blind hemming of trousers and lined and unlined jackets are performed with stitches 103, 105, 313.

Keywords: blind stitching, men suit manufacturing, curved needle, machine stitches, hemming, felling.

\section{ŠIVAĆE MAŠINE SLEPIH UBODA ZA IZRADU MUŠKIH ODELA DEO 1}

\begin{abstract}
Apstrakt: Odevna industrija koristi različite šivaće mašine koje zamenjuju manualne tehnike izrade šavova slepih uboda. Mnoge kompanije proizvode univerzalne i specijalne mašine za šivenje šavova slepih uboda. Zakrivljene igle mašina prave različite ubode klasa 100 i 300. Mašine izvode šablon šavova 1:1, 1:2 I 1:3. Napredne mašine osiguravaju kraj šava sa jednim čvorom ili nekoliko uboda ojačanja na istom mestu. Mašine mogu da izvrše automasko odsecanje konaca, podizanje papučice i pocizioniranje ilge. Mašine su izrađene za šivenje materijala različitih osobina. Mašine za izradu specifičnih operacija su opremljene sa raličitim pomoćnim aparatima. Porubljivanje sa šavovima slepih uboda se rade sa ubodima 103, 105, 313.
\end{abstract}

Ključne reči: slepi ubodi, izrada muških odela, zakrivljena igla, mašinski ubodi, porubljivanje.

\section{INTRODUCTION}

In 19th century men's fashion became more simple in shapes and colours. Next to the tailored men suits their industrially manufactured cheaper variants appeared. Since the Industrial Revolution, most part of men suits are mass-produced, and, as such, are sold as ready-to-wear garments. Due to these changes, the suits became accessible for people of all class
[1]. In 20th century the suit became the most popular all-purpose male costume. Advances in technology have given possibility to produce men suits in large quantities, standard sizes, and a different price levels [2].

Although today's suits significantly differ from their ancestors worn by men in previous centuries, they keep the their most important features - high 


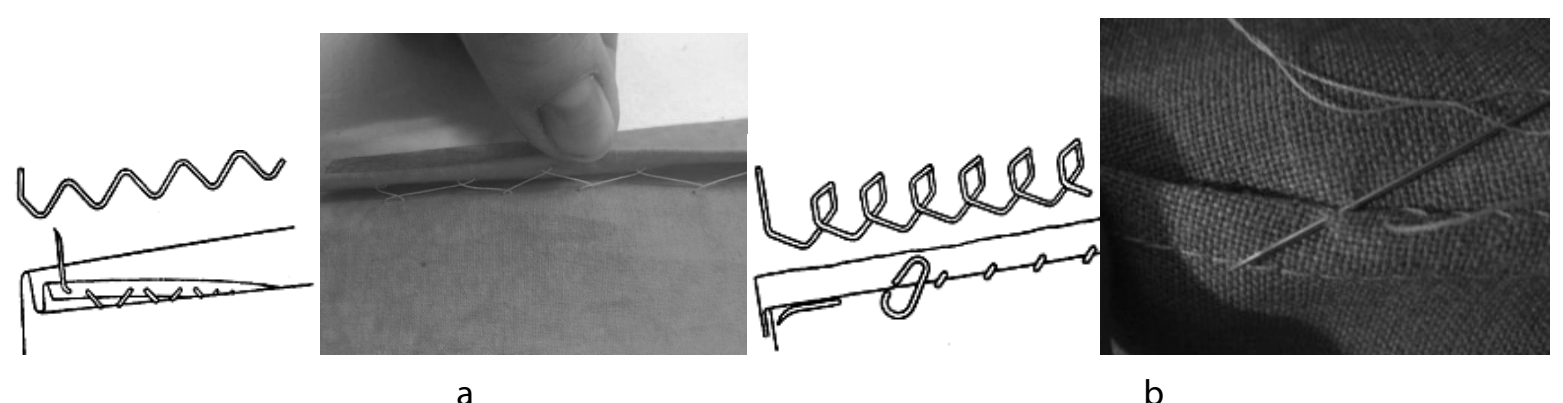

Figure 1: Hand stitches for invisible hemming: stitch type 213 (a) and 214 (b)



a

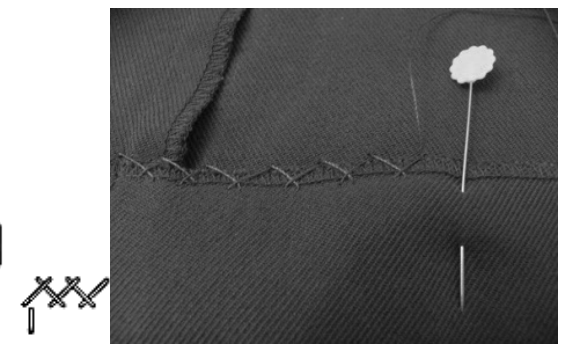

b

Figure 2: Hand stitches type 219 used for padding lapels and collars

(a) and type 204 used for attaching undercollars

quality, perfect fit, neat and elegant look which was obtained by hands of skilful and experienced tailors.

The neat look and perfect shape of the tailored suit, as well as, ability to maintain these features during all wear time of the suit; is created by help of large number of invisible hand stitches and seams used (see Fig.1, 2). However, because of manual and time-consuming work process, traditional tailoring techniques are not acceptable in industrial manufacturing. Garment industry has developed different kind of machinery which replaces manual sewing techniques to ensure much higher work productivity $[10,12]$.

In 1920 company "Strobel" developed the first single thread blindstitch machine for invisible edge hemming [5]. Nowadays many companies produce universal blindstitch machines for men suit and other garment manufacturing. There are many other specialized blindstitches machines which perform different technological operations in highly efficient way.

\section{THE MAIN CHARACTERISTICS OF INDUSTRIAL BLINDSTITCH MACHINES}

To create invisible stitches from one or both sides of the garment, blind stitch machine uses a curved needle (see Fig. 3.a, 5). When the needle passes a seam, by help of a presser/ plunger (see Fig.3.b) the fabric is raised that much that the needle picks up only few threads from the lower fabric ply to create invisible stitch from the bottom side of the material. The plunger is fixed on a spring which springs down at the places of cross seams, pleats, pocket bags, belt

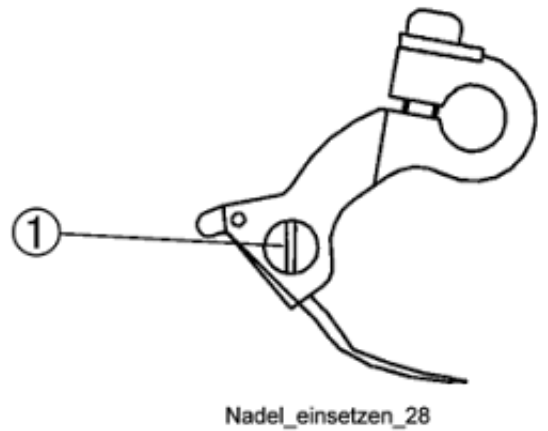

a

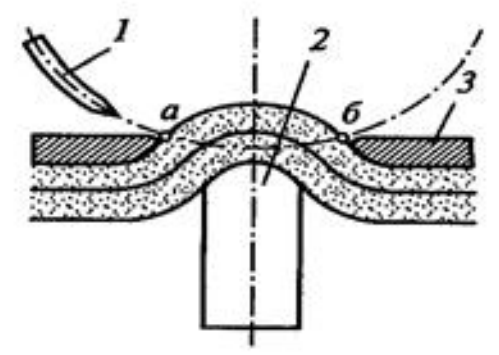

b

Figure 3: Curved needle (a), and blindstitch formation principle (b):

1- needle, 2 - plunger/presser, 3 - needle plate 


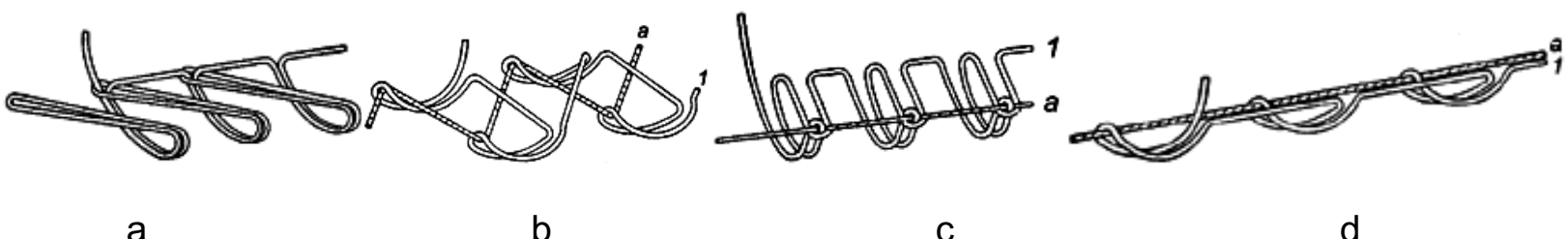

Figure 4: Machine stitches 103 (a), 313 (b) and 314 (c) and 317 (d)

loops etc., so that the needle never pierces through the lower fabric ply.

Blind stitch machines create different type of machine stitches. Single thread chain stitches of a class 100 are used the most often (see Fig. 4a). Some technological operations are performed also by two thread lockstitches class 300 [5,6], (see Fig. 4b,c,d).

During the work process the needle performs forwards and backwards movement (the needle swings) in different directions. Creating chainstitches class 100 the needle swings in across direction of the seam (stitch 103, 105). Creating lockstitches class 300 the needle swings in direction of the seam (stitches 313, $314,317)$. If the machines perform zig-zag stitches, the needle has one more movement way - perpendicular to the seam direction (stitches 105, 313, 314).

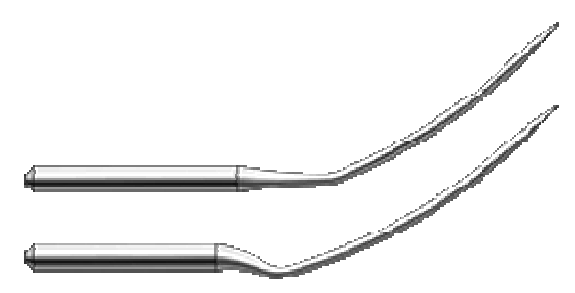

Figure 5: Curved needles of blindstitch machines

The most part of blind stitch machines perform more than one stitch pattern - 1:1, 1:2 and 1:3. Using stitch pattern 1:1 the needle enters the bottom fabric ply creating every stitch. This patter is used for blind- stitch seams on thicker fabrics and in situations when durability of seams is very important, for example, hemming trousers and skirts. Choosing "skip stitch" option 1:2 the needle penetrates bottom fabric lay forming every second stitch only. This way the seam is less noticeable on the face side manufacturing garments from light and delicate fabrics. With stitch pattern 1:3 the needle penetrates bottom fabric lay forming every third stitch only.

Single thread chainstitches class 100 unravel very easy. This disadvantage and the fact that threads in a blindstitch seam have to be loose as possible (to be invisible from the face side of the garment), are the reasons why special attention always has to be put to securing of the seam end. The advanced blindstitch machines secure the end of the seam in two different ways: creating one invisible thread knot/interloop before thread is cut off (Yamato, Maier, Strobel) or forming several spot/tack stitches which are visible only on the top ply of material (Strobel), (se Fig.6).

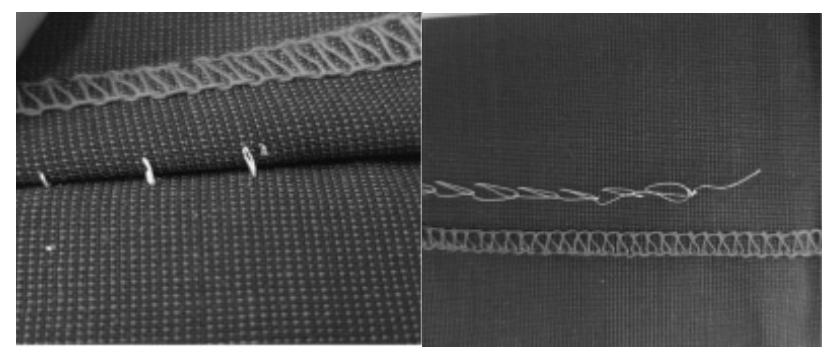

Figure 6: Spot tacking stitches at the end of the seam to secure it (Strobel)

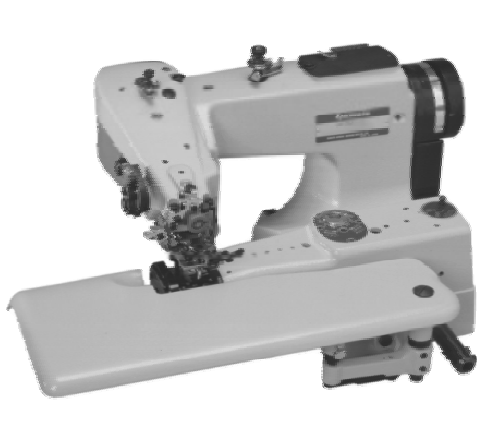

a

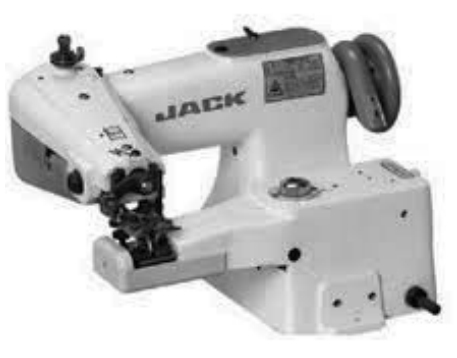

b

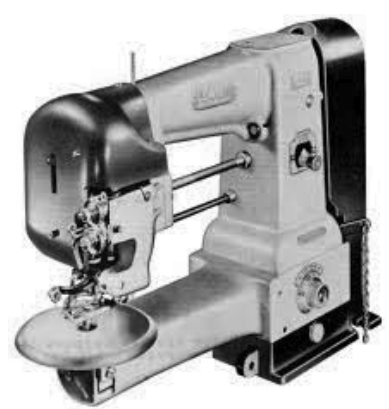

C

Figure 7: Machine with a changeable work surface (a), a cylinder arm (b) and round work surface (c) 
Most often blindstitch machines have changeable work surface/bed $[5,10,12]$ which is formed from a cylinder arm and a swing away workplate (support platform, flatbed, movable swing plate) to process flat and also circular garment parts (see Fig. 7.a). Specialized machines for processing narrow circular objects (sleeves, trousers, gloves, socks) have different diameter $(55 \mathrm{~mm}, 60 \mathrm{~mm}$ ) cylinder arm only (see Fig. 7.b). Spot tacking machines have small round work surface (see Fig.7.c).

Advanced blindstitch machines use to have automatic thread cutter, presser foot lifter and needle positioner $[6,7,8]$. The machines differ in: stitch length, sewing speed, material feeding way, number of plungers, needle plate opening and other parameters [9].

The blindstitch machines use to be developed for processing different quality materials: light, thick, for blind stitching of velvet, velour or universal use. Many specialized machines are developed to perform certain technological operations in highly efficient way [6].

\section{MACHINES FOR HEMMING OPERATIONS}

Edge hemming operations may be performed with different machine stitches - chainstitches type 103,105 or lockstitches type 313. In garment manufacturing hemming with stitches 103 is the most often used blindstitching operation.

\subsection{Blindstitch machines of single thread chainstitch 103 for hemming trousers (single blind stitch machines)}

Manufacturing men suits trousers are hemmed with machines of stitches 103. The hemming seam can be located on the folded fabric edge or at certain distance from it (see Fig. 8). Sewing speed of the machines - up to 3500 stitches per minute.

Hemming machines of stitches 103 are produced by many different companies: Strobel, Maier, Japsew, Global, Brother, Highland, US blindstitching, others.

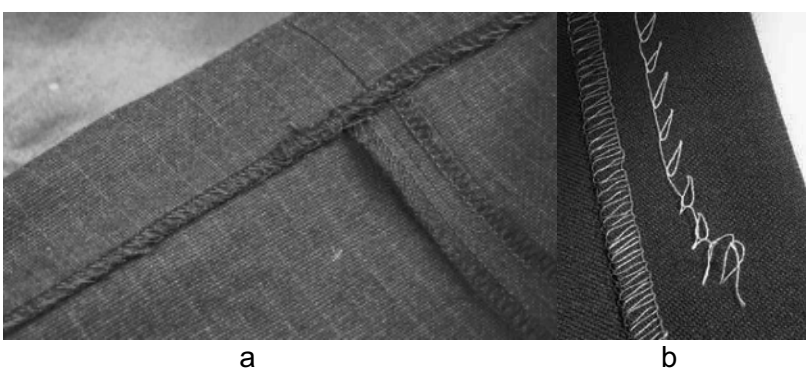

Figure 8: Hemming seam is located on the fabric edge (a) or at certain distance from it (b)

\subsection{Bindstitch machines of single thread chainstitch 105 for hemming trousers and un-lined jackets (double blindstitch machines, bluff edge blindstitch machine)}

Machines of stitches 105 form zig-zag stitches which are hidden between two folded fabric plays (called bluff edge blindstitch), (see Fig. 9.), [10]. Manually or by help of a fabric feeder (S-shape fabric feeder) the hem fold is partly "opened". When two plungers alternately raise the fabric from both hem's fabric plies (from the right and left), the needle picks up few threads and creates zig-zag stitches. After the hem fold is "closed" again, the seam becomes invisible. The seam can be placed at any required distance from the edge of the hem. Sewing speed - up to 2500 stitches per minute. The machines are produced by companies: Strobel, Maier, Japsew, others. Unlined or halflined jackets may be also hemmed with machines of stitches 313.

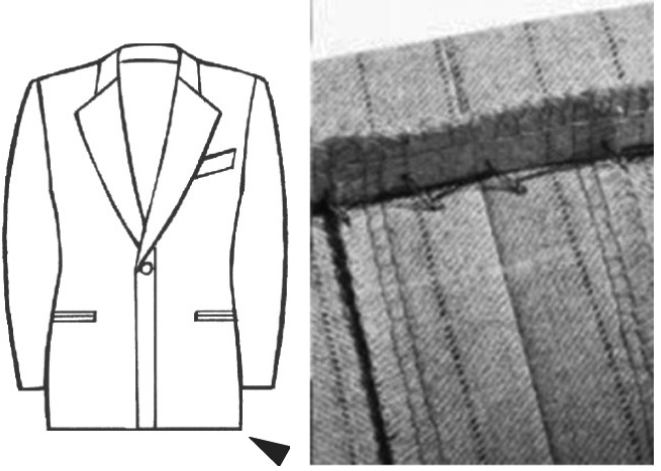

Figure 9: Seam with blindstitches 105

\subsection{Machines of two thread lockstitches 313 for hemming lined jackets (felling machine for hems of linings)}

In high quality tailored jackets folded hem is fixed with hand bilndstitches in all its length. It guaranties a sharp and fixed hem line during wear of the jacket, as well as, after its dry cleaning and ironing/ pressing. The linen can be fixed with a jacket using conventional lock-stitch machine of stitches 301 . However, then the hem allowance is tacked at the jacket seams only and the hem line is loose.

Machines of blind lockstitches 313 (see Fig.10) are used in industrial manufacturing of men suits [10].To create zig-zag stitches the curved needle of a machine swings in two directions. The movement in the direction of the seam is the main movement which determines the length of the stitch. The needle swings also 
in cross direction of the seam and this movement determines stitch width. Alternatively the needle penetrates into the lining and the face fabric. The machine uses two plungers. One of them is raising lining, other one - face fabric of the jacket. Both plungers can be adjusted independently in accordance with different qualities of the lining and face fabric to get invisible stitches on both materials. The fabric is transported by help of two feeders - a lower (to transport face fabric) and an upper/lateral feed dogs (to transport linen).

The seam can be placed in different distances from hem edge: $8 \mathrm{~mm}, 6 \mathrm{~mm}, 4 \mathrm{~mm}$ (smaller distance from edge is used for thinner materials). The speed of the machines is only up to 1300 stitches per minute.

The machines of stitches 313 are produced by companies: Strobel, Maier, Japsew, others.

\subsection{Machines of lockstitches 313 for hemming un-lined and half-lined jackets (hem felling on half-lined jackets)}

Manufacturing half-lined or unlined jackets the hem line is fixed with the same lockstitches 313 (see Fig.11). However, during the work process, a manufactured jacket has to be placed on the right from the needle. Therefore, the machines have a long arm
$(50 \mathrm{~cm})$ and larger work surface under it. The machine uses bottom and lateral feed [10]. The seam may be sewn in different distanced from the hem edge: $8 \mathrm{~mm}$, $6 \mathrm{~mm}, 4 \mathrm{~mm}$ (smaller distance from edge is used for thinner materials). Sewing speed - up to 1300 stitches per minute.

The machines for hemming unlined jackets are produced by companies: Strobel, Maier, others.

\subsection{Machines of stitches 103 for hemming seam allowance of un-lined and half-lined jackets (bookseaming machines)}

To get neat and elegant look tailoring high end unlined and half-lined jackets, the allowances of seams use to be folded down/ hemmed and fixed with invisible hand stitches. The special industrial blindstitch machines are developed to imitate such tailoring method (see Fig.12), [10]. These seams are called bookseams. To fold the seam allowances down, the machines are equipped with special folders for different hem width and fabric thickness. The tension of the thread has to be minimal as possible, to create fully invisible stitches on the face side of the garment [13]. Sewing speed - up to 3000 stitches per minute. The bookseaming machines are produced by companies: Strobel, Maier, US blindstitching.

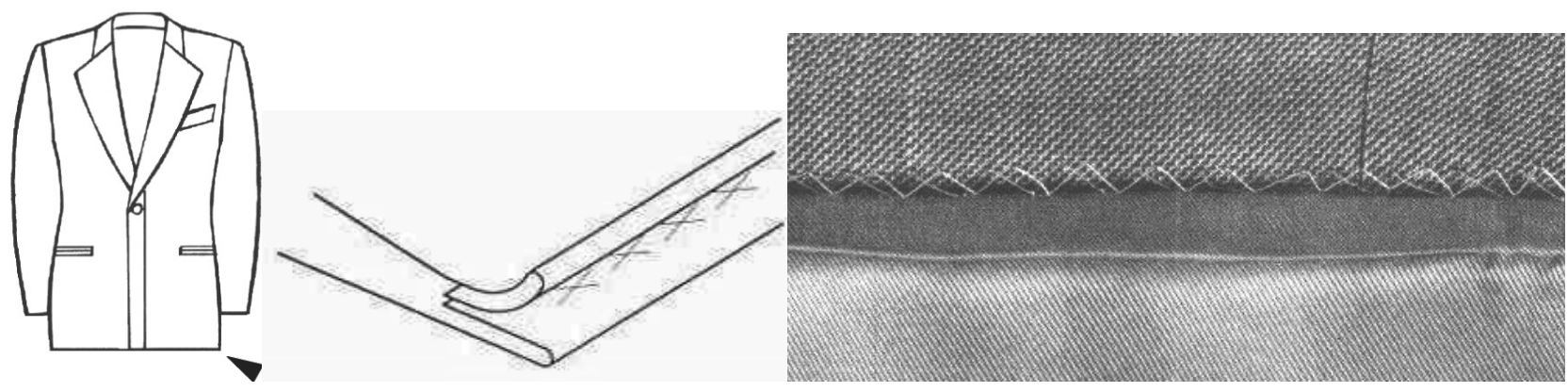

Figure 10: Hemming seem fixes the lining of a jacket

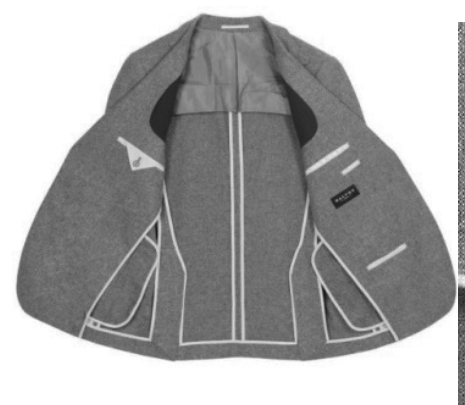

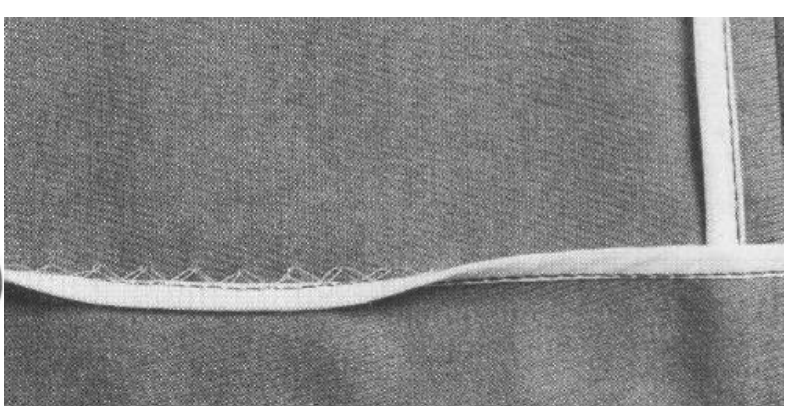

b

Figure 11: Half lined jacket (a) and hemming seam with stitches 313 (b) 

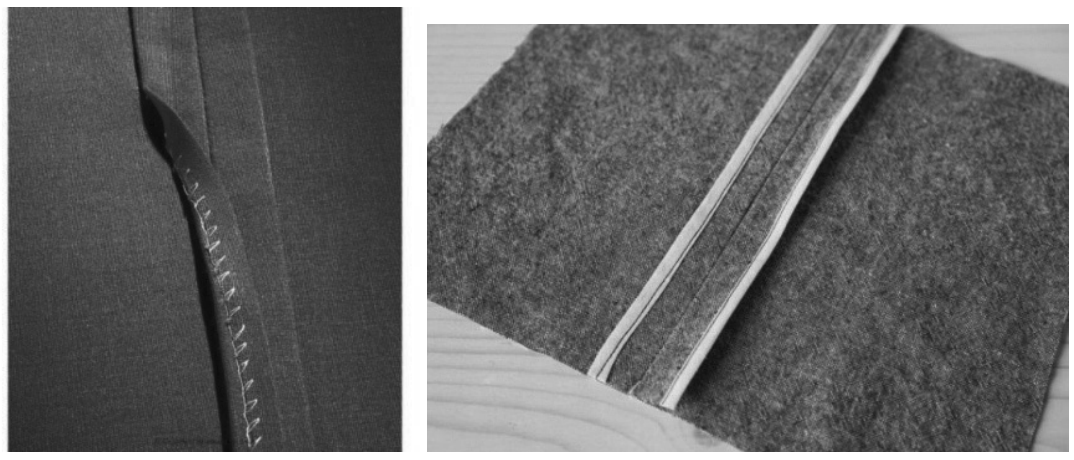

Figure 12: Bookseams (a) and seams fixed with a bias band (b)

\section{CONCLUSION}

Blindstitch machines of stitches 103, are used for hemming men trousers, as well as, for hemming many other kinds of garments, such as, skirts, dresses, jackets, coats, women trousers. Therefore, among different blindstitch machines they may be called universal/basic machines. The seams of stitches 105 are fully invisible on the ready garment. This is advantage of the machines of the stitch 105. Because of necessity to create zig-zag stitches, their stitch formation mechanism is more complicated, sewing speed is a lower, but price is higher. The slowest are machines of stitches 313 as they also create zig-zag stitches and stitches are placed on different quality fabrics - on the face fabric and light lining.

Generally, blindstitch machines work with much lower speeds than other kind of sewing machines. The fact that the seam has to be invisible from one or both side of the ready garment demand careful regulation of the machine's stitch parameters, assistance of a skilful operator and speed limits to ensure qualitative stitching process.

\section{REFERENCES}

[1] Diduch R. J. Hand tailoring, available in: https://tuttofattoamano.blogspot.com/search/ label/Hand\%20Tailoring

[2] Cabrera R., Antoine D. (2015). Classic Tailoring Techniques for Menswear. Bloombury.

[3] Musgrave E. (2019). Sharp Suits: A celebration of men's tailoring. Pavilion Books, 2019. Gentleman's Gazette.

[4] History of the suit, available in: https://www. gentlemansgazette.com/evolution-of-menswearsuits/

[5] Strobel.History. available in: https://www.strobel. biz/sod/index.php?page=uk_unternehmensgeschichte

[5] ISO 4915:1991(en) Textiles — Stitch types - Classification and terminology
[6] Colovic G. (2015). Sewing, stitches and seams. In: In: Nayak R., Padhye R. ed. Garment Manufacturing Technology, Woodhead Publishing, Elsevier, Cambridge, 247-273.

[7] Jana P. (2015). Sewing equipment and work aids. In: Nayak R., Padhye R. ed. Garment Manufacturing Technology, Woodhead Publishing, Elsevier, Cambridge, 275-314.

[8] Nayak R. Padhye R. (2017). Automation in Garment Manufacturing, Woodhead Publishing, Elsevier, Cambridge.

[9] Jana P. (2018). Automation in sewing technology. In: Nayak R., Padhye R.ed. Automation in Garment Manufacturing. Woodhead Publishing, Elsevier, Cambridge, Pages 199-236.

[10] Blindstitch machines, available on: http://muriscut.com/blindstitch-machines/

[11] Mcloughlin J., Mitchell A. (2013). Mechanisms of sewing machines. In: Jones I., Stylios G.K. Joining Textiles. Woodhead Publishing. Cambridge, 123-148.

[12] Hayses S., Mcloughlin J. (2018). The sewing textiles. In: Jones I., Stylios G.K. Joining Textiles. Woodhead Publishing. Cambridge. 62-120.

[13] Jankovska M., Demboski G. (2018). Effect of fabric structure variation on needle thread tension and thread consumption on sewing machine. Tekstilna Industrija, 66(2), 16-22.

Primljeno/Received on: 31.01.2021.

Revidirano/ Revised on: 26.04.2021

Prihvaćeno/Accepted on: 28.04.2021.

○ 2021 Authors. Published by Union of Textile Engineers and Technicians of Serbia. This article is an open access article distributed under the terms and conditions of the Creative Commons Attribution 4.0 International license (CC BY) (https://creativecommons.org/licenses/by/4.0/) 